\title{
CALIFORNIA'S WORKMEN'S COMPENSATION LAW: COMPUTATION OF PAYMENTS FOR PERMANENT DISABILITIES SUSTAINED BY A PREVIOUSLY DISEASED OR DISABLED EMPLOYEE
}

Under the California Workmen's Conupensation Law the surviving injured workman is entitled to payment by the employer of medical and hospital treatment of the injury, ${ }^{1}$ and to indemnity benefits for the disability resulting from such injury. ${ }^{2}$ The computation of these disability benefits raises considerable difficulties in cases of permanent disablement, difficulties which are increased if the compensable injury occurs to a workman suffering from a previous physical handicap. The purpose of this comment is to clarify questions of apportionment of hability for disabilities which combime with existing disabilities, impairments, or diseases. This requires, as a first step, an explanation of disability payments.

\section{I}

\section{THE NATURE OF DISABILITY PAYMENTS}

Depending upon its severity and duration, a disability is classified as one of four types: (1) temporary partial disability; (2) temporary total disability; (3) permanent partial disability; and (4) permanent total disability. Although "disability" as such is not defined in the statute," the objectives of disability payments are revealed by the prescribed method of computing the benefits for each type of disability. Temporary disability payments, whether for total or partial disability, are measured by actual loss of earnings, such loss being computed on the basis of the average weekly earnings of the injured employee. ${ }^{5}$ Permanent disabilities,

1 Car. Lab. CODE $\$ \S 4600-05$.

2 CaL. Lab. CoDE $\S \S 4650-63$.

3 The rules relating to temporary disabilities are found in CAL. LAB. CODE $\$ \$ 4650-57$, those relating to permanent disabilities in CAL. LAB. CODE $\$ \$ 4658-63$. See generally 2 LARSON, THE LAW OF WORKanEN's COMPENSATION $\$ 57.10$ (1961). The distinction between permanent and temporary disabilities is a question of fact. A permanent disability is one which will remain substantially the same during the remainder of the injured person's life. Subsequent Injuries Fund v. Industrial Acc. Comm'n [Rogers], 226 A.C.A. 199, 206, 37 Cal. Rptr. 844, 849 (1964). "Permanent" does not mean "stationary." Dahlbeck v. Industrial Acc. Comin'n, 135 Cal. App. 2d 394, 287 P.2d 353 (1955).

4 It has been recommended that a definition be made, CaL. Senate Comar. on Labor, Second Partial Regort Relating to Workamen's Compensation 11 (1955) [hereinafter cited as Second Partial Report]. A comprehensive substantive definition of the term "disability" for the purposes of CAI. LAB. CoDE $\$ 4751$ was attempted in A.B. 213, Reg. Sess. (1959). The term "injury" is defined in CAL. LAB. CODE § 3208: "Injury includes any injury or disease arising out of the employment, including injuries to artificial members, dentures, eyeglasses and medical braces of all types. ..."

5 CAx. LaB. Code $\S \S 4653-54,4657$. 
by contrast, are measured not by actual loss of earnings, but by a composite standard which takes into account "the nature of the physical mjury or disfigurement, the occupation of the injured employee, and his age at the time of such injury, consideration being given to the diminished ability of such injured employee to compete in an open labor market." The degree of disability is expressed as a percentage of total disability. ${ }^{7}$ This percentage figure is in turn the basis for the determination of the number of weeks during which the injured workman is entitled to payments. Permanent disability in excess of seventy percent gives rise to lifelong benefits. Permanent disability below seventy percent is compensated by payments for a limited time only, from four to 280 weeks, corresponding to disabilities ranging from one to seventy percent. ${ }^{8}$ Ultimately, then, permanent disability is translated into a number of benefit weeks. Only at this point are average weekly earnings to be considered, to determine the dollar amount of the weekly payment. The rationale of this scheme of permanent disability payments is not compensation for the loss in the sense of damages awarded in a personal injury judgment. The number of weeks is, rather, an estimate of the time the injured person will need in order to adjust himself to working, hampered by a permanent plyysical impairment; lifelong benefits are granted when the disability is so severe as to render rehabilitation comparatively negligible. In both cases the payments are intended not only as assistance to the workman during a period of reduced earning capacity, but as indemnity for his residual permanent disability. ${ }^{\circ}$

\section{II}

\section{THE RATING OF PERMANENT DISABIIITIES}

\section{A. Single Disabilities}

For the majority of so-called objective disabilities, ${ }^{10}$ the percentage of permanent disability of an injured workman is determined by means

${ }^{6}$ CAC. LAB. CoDE $\$ 4660$ (a). The payment of benefits regardless of actual wage loss was held constitutional in Madin v. Industrial Acc. Comm'n [Richardson], 46 Cal. 2d 90, 292 P.2d 892 (1956).

7 Cax. Lab. Code $\$ 4658$.

8 CaL. LAB. CODE $\$ \$ 4658-59$.

${ }^{8}$ For the roles which physical impairment and reduced earning capacity assume in different concepts of disability, see Riesenfeld, Disability and the Law of Workmen's Compensation, as excerpted in U.S. Dep'T of Heatte, Educatton aNd Wetrare, Rebabititating THE DisabLeD WORKER 59-65 (1963).

10 A disability is called objective if it can be ascertained by means of extraneous evidence. The loss of a member, for instance, can be seen. A disability is called subjective if the disabled person's testimony is necessary in order to establish the kind and degree of disablement. An example of subjective disability is headaches. See 1 HANNA, TrEE LAW of EMTPLOYEE INJURJES AND WORKMEN's COMPPENSATION 248 (1953) [hereinafter cited as HANNA]. 
of the "Schedule for Rating Permanent Disabilities,"11 adopted by the Industrial Accident Commission pursuant to Cahifornia Labor Code section 4660 (b). In use since 1914, the schedule has from time to time been subject to severe criticism, ${ }^{12}$ yet basically it has remamed unchanged. ${ }^{13}$ The schedule is designed to achieve consistent results in the application of the factors which must be considered under Labor Code section 4660 (a): the nature of the physical injury, occupation and age, and the diminished enployability. Its basic table contains standard ratings for over 300 injuries, fixed with regard to the average man of thirty-nine, without special occupational skills. ${ }^{14}$ For example, a minor impairment of the function of the wrist is rated seventeen percent; ${ }^{15}$ the shortening of one leg by two inches is rated twenty percent; ${ }^{16}$ loss of the sense of taste is rated five percent. ${ }^{17}$ The schedule also contains a number of subjective disabilities, ${ }^{18}$ such as impaired function of the spine, which are given the categories of shight, moderate or severe, rating thirty, fifty or 100 percent respectively; ${ }^{19}$ the exact percentage rating is based upon the expert's evaluation of the individual employee. For this evaluation, the Commission has adopted certain guidelines and definitions. ${ }^{20}$

In addition to the percentage figure, each scheduled injury is also characterized by a number. A second table lists over 1800 occupations which are collected in sixty different occupational groups. By means of

11 Hereinafter cited as Schedule. A partial reprint of the standard ratings in the schedule may be found in 1 HANNA 252-54.

12 Studies have shown that the schedule does not guarantee consistent ratings and that the schedule's variations for the different occupations are not differentiated enough in order to yield fair results. CaI. SEnate Comom. on Labor, ThIrd REport Relating to Workanen's COMIPENSATION 7, 14-19 (1955) [hereinafter cited as THIRD REPORT]. For criticism from a medical point of view, see KEsSLER, ACCIDENTAL INJURIES 44-45 (1932). For criticism from various interest groups such as attorneys- and employers, see THIRD REPORT 28-30.

13 THIRD REPORT at 9.

14 Id. at 13 .

15 Schedule at 7.

16 Id. at 14.

17 Id. at 5 .

18 See note 10 supra.

10 Schedule at 13.

20 The recommendations and definitions adopted by the Commission on June 26, 1956, are stated as follows: Subjective Disability can best be evaluated by: (1) A description of the activity which produces the disability, (2) the duration of the disability, (3) the activities which are precluded and those which can be performed with the disability, (4) the means necessary for relief. Definitions developed are: (1) A severe pain would preclude the activity precipitating the pain, (2) a moderate pain could be tolerated, but would cause marked handicap in the performance of the activity precipitating the pain, (3) a slight pain could be tolerated, but would cause some handicap in the performance of the activity precipitating the pain, (4) a minimal (mild) pain would constitute an annoyance, but causing no handicap in the performance of the particular activity, would be considered as nonratable permanent disability. Cal. Dep't of Industrial Relations, Intra-Departmental Communication of July 1, 1961. 
a third table, the disability number and the occupational group number are combined into a modification symbol (letters $A$ througl $L$ ). This symbol is then applied to the basic percentage rating of the first table, in order to yield the modification of that basic rating for the occupational variation. The result is the correct percentage of disability for the employee at age thirty-mine. The fifth and last table of the schedule applies the factor of age to derive the final modification of the standard rating.

Under Labor Code section 4660 (b), the schedule is prima facie evidence of the disabihty percentage attributable to each injury covered by the schedule. In the large number of cases which are decided by the Commission entirely on the basis of written reports, ${ }^{21}$ the schedule rating will be adopted as the final result.

As a matter of course, the standard rating table does not contain all possible injuries and disabilities. ${ }^{22}$ Non-scheduled disabilities are to be evaluated "by comparison with the nearest scheduled disability, or by analogy to a scheduled disability, or by comparison with the entire scheme of relative severity of disabilities." ${ }^{\prime 23}$ For some subjective disabilities, notably those resulting from pam, the schedule is not useful at all. ${ }^{24}$ In these cases, the proper rating is based on a direct application to the individual case of the standards laid down by Labor Code section 4660(a).

The most difficult group of cases which cannot be rated from the schedule alone are those in wlich the disability complained of is due to the aggravation of a prior disease. To avoid confusion, it must be explained that a disease does not necessarily constitute a disability in the technical sense. An arrested disease, for instance, or a disease in its beginning stage may be medically ascertainable without diminisling a person's capacity to work and without causing noticeable physical impairment. In such cases, however, the prior disease may be a contributing cause of the disability resulting from an industrial accident, a cause wlicli of itself might or might not have produced some disability. There is no aggravation of a prior disability, but an aggravation of a disease which now results in disability. Since the employer is liable for employnentconnected disabilities only, ${ }^{25}$ it becomes necessary to distinguish the natural progress of the disease and the industrial accident as two separate sources of the employee's total condition. Labor Code section 4663 provides:

211 HANNA 87-89.

22 For an enumeration of the various disabilities not covered by the schedule, see Trmo REPORT at 10.

28 Schedule at 1.

24 For the rating process in such cases, often called "judgment rating," see Tumo REPORT at 10 .

25 CAI. LAB. CODE $\$ 3600$. 
In case of aggravation of any disease existing prior to a compensable injury, compensation shall be allowed only for the proportion of the disability due to the aggravation of such prior disease which is reasonably attributed to the injury.

Accordingly, disablement from the aggravation of a prior disease is compensable as far as it is caused by the industrial injury, but not compensable to the extent to which it is due to the natural progress of the disease. ${ }^{26}$ Cases under section 4663 are therefore solved by asking: Did the present disablement or a part thereof result from the natural progress of the pre-existing disease? If the answer is no, the employer is liable in full. This is true even where the disease was a necessary cause which combined with the industrial cause in bringing about the disability. ${ }^{27}$ Cases in which a prior disease has been arrested so that without the industrial accident the disease would have remained asymptomatic do not therefore entitle the employer to an apportionment of the newly created disability. On the other hand, if the total present condition developed irrespective of the employment, then the employer will not be liable at all. If the injury accelerated a naturally progressing disease, as, for instance, a back injury may accelerate an already existing arthritis, the employer will be liable for this acceleration. ${ }^{28}$

Frequently the mamifestations of a disease belong to the group of subjective disabilities. Stiffness and pain caused by arthritis do not result in standard impairments; even without regard to apportionment, the schedule is therefore not directly applicable. ${ }^{29}$ In cases where the disease results in an objective disability, as where a cancerous tumor, aggravated by trauma in an industrial accident, necessitates the amputation of a foot, the effect of section 4663 is to render the schedule inconclusive so long as part of that disability is a natural development of the pre-existing disease. ${ }^{80}$ In those cases the schedule may, however, be useful $\mathrm{m}$ indicating,

26 De La Tova v. Industrial Acc. Comm'n, 137 Cal. App. 2d 516, 290 P.2d 377 (1955).

27 Hendrickson v. Industrial Acc. Comm'n [Lieska], 215 Cal. 82, 8 P.2d 833 (1932) (crippled hand resulted from blood poisoning in a diabetic after minor injury); Argonaut Ins. Co. v. Industrial Acc. Comm'n [Harris], 231 A.C.A. 136, 41 Cal. Rptr. 628 (1964) (construction work over a period of eight years found a cause of employee's progressing disc pathology); Truck Insurance Exch. v. Industrial Acc. Comm'n [Paalman], 24 Cal. Comp. Cas. 53 (1959) (back disability and prior non-disabling arthritis); Maltony v. Fisher Body Div. of Gen. Motors Corp., 22 Cal. Comp. Cas. 52 (1957) (back and shoulder disabilities in employee suffering from non-disabling arthritic condition).

28 The leading case is Tanenbaum v. Industrial Acc. Comm'n, 4 Cal. $2 \mathrm{~d} 615,52$ P.2d 215 (1935).

20 See text accompanying notes 22-24 supra.

80 Where an operation was necessary even in the absence of the industrially caused aggravation, the wage loss could not be charged to the employer. See Allied Compensation Ins. Co. v. Industrial Acc. Comm'n [Etkins], 211 Cal. App. 2d 821, 27 Cal. Rptr. 918 (1963) (temporary total disability during hospitalization). 
as an upper limit, the rate for the combined results of progression and acceleration.

Since section 4663 serves to limit the employer's liability to employment-connected results, prior manifestations of the contributing disease are relevant evidence to show that certain portions of the present impairment would exist even without the accident. That the disease had previously not resulted in disability is, however, not conclusive evidence of a disability wholly chargeable to the industrial accident. The frequently encountered statement that the aggravation of an asymptomatic disease does not entitle the employer to an apportionment ${ }^{31}$ is misleading if the term "asymptomatic" is not restricted to describe arrested conditions. Disablement from a prior disease that was not arrested may require apportionment even though the disability becomes manifest only subsequent to and in connection with the industrial accident. ${ }^{32}$

In practice, the problems here arise less from the interpretation of the statute than from the uncertainties inherent in the medical evaluation of diseases bike arthritis and arteriosclerosis. The question to the medical expert, whether a heart attack or a stiff back would have occurred even without the industrial accident, is almost unanswerable. Medical evidence is more easily obtainable to the effect that the disability would not have resulted from the industrial mjury alone and that the disease was a material cause of the disability. ${ }^{38}$ According to the weight attributable

31 E.g., Industrial Indem. Co. v. Industrial Acc. Comm'n [Thomas], 95 Cal. App. 2d 443, 213 P.2d 11 (1949); Vilas Amstutz, Zemith Nat'l Ins. Co. v. Industrial Acc. Comm'n [Doss], 28 Cal. Comp. Cas. 2 (1963) ; Maltony v. Fisher Body Div. of Gen. Motors Corp., 22 Cal. Comp. Cas. 52 (1957).

32 Section 4663 has to be clearly distinguished from $\$ 4750$. Section 4663 does not deal with the apportionment of pre-existing and subsequent disabilities, but with diseases which may or may not have been labor disabling before the industrial accident. If it can be established medically that a person who was not disabled previously would have become disabled from his progressing disease even without the industrial accident, the employer will not be hable for the total resulting disability. See, e.g., Subsequent Injuries Fund v. Industrial Acc. Comm'n [Harris], 44 Cal. 2d 604, 283 P.2d 1039 (1955); State v. Industrial Acc. Comm'n [Bachrach], 147 Cal. App. 2d 818, 306 P.2d 64 (1957). In both cases the employer's liability was only partial although the prior disease had not manifested itself in labor disability.

On the other hand, a disease already may have been labor disabling before the subsequent accident. In such a case, both $\$ \$ 4663$ and 4750 are applicable: the pre-existing disability is charged to the employee in any event $(\$ 4750)$. The subsequent disability is separated between natural progress and industrial aggravation or acceleration under $\$ 4663$. See note 75 infra and the accompanying text.

See also Second Partiat Report 18-19. The report condemns the practice of the Industrial Accident Commission of requiring previous mamifestation of labor disability before making an apportionment.

33 Testimony of Carlyle Stout, M.D., Hearings before the California Senate Commillee on Labor, Nov. 9, 1955, in CaI. Senate Comor. on Labor, Partiat Report Relating to WORKMEN'S COMPENSATION 359-60 (1955). As to the different use of the terms causation and aggravation by courts and medical experts, see McNiece, The Law Looks at Heart Dis- 
to the disease and the accident as contributing causes, a certain percentage of the disability is then in rough terms attributed to the prior disease. $^{34}$ This type of apportionment between medical causes is not clearly authorized by section $4663{ }^{35}$ Apportionment on a causation basis seems, however, more acceptable than inducing speculative evidence, or resolving the doubts against one of the parties. ${ }^{36}$ In cases of progressing diseases, apportionment on the basis of comparative causation is perhaps justified because it can reasonably be assumed that the disease would have produced some disability in and of itself. This argument is not available in cases of arrested diseases. There the principle should stand firm that the "lighting up of a dormant disease" which in itself would not have resulted in disability is charged to the employer. ${ }^{38}$

\section{B. Multiple Disabilities}

The inethod of rating permanent disabilities so far has been discussed for single injuries only. Indeed, the schedule system presupposes isolated consideration of each particular injury, since it attempts to attach equal benefits to equal injuries by means of standard percentage figures. Yet

ease, U.S. Dep'T of Labor, Bulletin 261, Workmen's Compensation Problems 82, 89 (1963).

34 E.g., Subsequent Injuries Fund v. Industrial Acc. Comm'n [Baldes], 53 Cal. 2d 392, 1 Cal. Rptr. 833, 348 P.2d 193 (1960) (personality disorder apportioned 25\% to industrial accident, $75 \%$ to pre-existing schizoid personality); De La Tova v. Industrial Acc. Comm'n, $137 \mathrm{Cal}$. App. 2d 516, 290 P.2d 377 (1955) (headaches after head injury apportioned 15\% to the injury, $85 \%$ to pre-existing habitual postural deviation).

35 Maltony v. Fisher Body Div. of Gen. Motors Corp., 22 Cal. Comp. Cas. 52 (1957). But see Second Partial Report 18-19, which expresses the opinion that historically $\$ 4663$ meant apportionment according to the relative weight of the industrial and non-industrial causes. Two bills introduced in 1963 for an amendment of $\S 4663$ sought to replace the present rule by apportionment on a mere causation basis. A.B. 1641 and A.B. 1924, Reg. Sess. (1963).

${ }^{86}$ In City of Glendale v. Industrial Acc. Comin'n [Enochs], 153 Cal. App. 2d 213, 314 P.2d 182 (1957), the Commission had refused apportionment of a heart disability on the ground that the evidence did not provide a basis for such a determination. The court annulled the award, holding that apportionment has to be made, even if difficult; to hold otherwise would violate the mandate of the legislature and would be unfair and inequitable to the employer.

87 Tanenbaum v. Industrial Acc. Comm'n, 4 Cal. 2d 615, 52 P.2d 215 (1935).

88 In Walsh Constr. Co. v. Industrial Acc. Comm'n [Herrera], 22 Cal. Comp. Cas. 157 (1957), a 34 year old miner suffered a myocardial infarction after lifting a heavy block of wood. The Commission refused apportionment under $\S 4663$ in the "absence of medical evidence indicating that the arteriosclerosis would ever have disabled Herrera in the absence of such a severe strain . ..," 22 Cal. Comp. Cas. at 158 (1957). See also Hendrickson v. Industrial Acc. Comm'n, 215 Cal. 82, 8 P.2d 833 (1932); Idaho Maryland Mines Corp. v. Industrial Acc. Comm'n [Duncan], 104 Cal. App. 2d 567, 232 P.2d 11 (1951). Since few diseases can be judged to remain benign and non-disabling, there are few cases illustrating this principle. In most disease cases, the expert evidence indicates that some disability would bave occurred even in the absence of an industrial accident. See cases cited at note 34 sitpra. 
frequently a compensable accident involves more than one member or bodily part of the employee and results in more than one scheduled or non-scheduled disability. The presence of contemporaneously incurred other physical impairments then will affect the results of the injury under consideration, both medically and with respect to the workman's ability to compete in the labor market. For instance, the disability of a man who loses an arm in an industrial accident is influenced by the fact that at the same time he loses a leg.

The total percentage rating of such multiple injuries is suggested in a Table for Determining Multiple Disability Ratings, which is contained in a supplement to the schedule. This table is not a part of the schedule, and hence is not prima facie evidence of the percentage figures; it is published by the Commission "to serve as a guide." ${ }^{30}$ The table seems to be applied $\mathrm{m}$ most multiple disability cases, ${ }^{40}$ whether the disabilities involved are all scheduled, non-scheduled, or mixed. Its purpose is to reduce the sum resulting from the addition of the percentage ratings for each disability, on the theory that the second, third, and further disabilities only aggravate the main disability. The deduction suggested for two disabilities may be illustrated by the concurrence of a fifty percent and a twenty-five percent disability. Instead of a total disability rating of seventy-five percent, the table indicates only sixty-five percent. The resulting deduction in the number of benefit weeks is justified since the rehabihitation for the two disabilities occurs contemporaneously, not successively, thus shortening the over-all period of adjustment. Where more than two disabilities are present, the effect of each further disability on the first combination is determined by another application of the schedule.

The table is expressly made inapplicable to "multiple disability factors in a single extremity," and to "bilateral disabilities" (such as disability in both legs)..$^{41}$ For such cases the scliedule itself regulates the effect of the simultaneous occurrence of multiple disabilities. The combined disability rating may either be smaller or greater than the sum of the individual disability percentages, depending upon the nature of the injuries. When the combined disability is rated less than the sum of the component disabilities, the schedule ratings represent special applications of the abovementioned compression theory underlying the Multiple Disabilities Table. The reason for an increase in the number of benefit weeks beyond the

89 Schedule at 81.

40 E.g., Subsequent Injuries Fund v. Industrial Acc. Comm'n [Rogers], 226 A.C.A. 199, 37 Cal. Rptr. 844 (1964); State v. Industrial Acc. Comm'n [Springer], 129 Cal. App. 2d 302, 276 P.2d 820 (1954).

41 Schedule at 81. 
sum of the separately computed benefits is best shown by practical examples. Loss of five fingers, all at the proximal joint of the major hand, is rated by the schedule as a total of fifty-five percent disability. ${ }^{42}$ The straight sum of the percentages given for the five fingers separately amounts to forty-four percent. ${ }^{43}$ Implicit in this extension of benefits for the combined loss is the opinion of the framers of the schedule that the simultaneous loss of all fingers has a synergistic effect ${ }^{44}$ on the disability resulting from the loss of each single finger. Similar synergistic effects are recognized for loss of hearing, where imilateral deafness rates ten percent, bilateral deafness fifty percent, ${ }^{45}$ and for loss of vision, where blindness in one eye rates between twenty-five and thirty percent, and total blindness rates one hundred percent. ${ }^{46}$

In cases of non-scheduled disabilities or mixed disabilities, the mitigating or synergistic effect of the particular combination is presumably subsumed within the total judgnent rating. If various subjective disabilities are rated separately, and if reduction of the total disability figure seems proper, the Multiple Disability Table may be used to determine the standard reduction.

Outside the scheme of the schedule are the disabilities enumerated in Labor Code section 4662. Loss of both eyes, loss of both hands, total paralysis and insamity are conclusively presumed to be total disabilities.

\section{III}

THE RATING OF SUBSEQUENT DISABILITIES

\section{A. The Principle of Apportionment}

If a physically handicapped employee sustains an industrial injury, his employment-connected disability is influenced not only by contemporaneous disabilities stemming froin the same industrial accident but also by his pre-existing disabilities. It is clear that the employer is not liable for previous disabilities, since they have not arisen from the employmentconnected injury for which compensation is sought. ${ }^{47}$ Congenital defects, prior diseases, the loss of a member sustained in an automobile accident, may all, however, increase or decrease the disability resulting from the subsequent injury, much as contemporaneous disabilities may have mitigating or synergistic effects upon each other. If full consideration were

42 Id. at 7-11.

43 Id. at 11.

44 The term synergistic is used to indicate that by virtue of their combination, each disability is rendered inore severe.

45 Schedule at 4.

46 CAL. LAB. CODE $\S 4662$ (a); Schedule at 3.

47 CaL. LAB. Code $\$ 3600$. 
given the four factors established in Labor Code section 4660 (a), a rating of the subsequent compensable injury would have to take into account whatever effect these previous impairments might have on the present physical condition and employability of the newly disabled workman.

The Cahifornia Workmen's Compensation Law has chosen a different approach. Labor Code section 4750 provides:

An employee who is suffering from a previous permanent disability or physical impairment and sustains permanent injury thereafter shall not receive from the employer compensation for the later injury in excess of the compensation allowed for such injury when considered by itself and not in conjunction with or relation to the previous disability or impairment.

The employer shall not be liable for compensation to such an employee for the combined disability, but only for that portion due to the later injury as though no prior disability or impairment had existed.

In slort, a subsequent disability is to be evaluated as if it were this employee's first single disability.

The policy reasons for this solution are usually shown in the context of the limited type of cases which prompted the drafting of section 4750 , namely, the synergistic disabilities. As a matter of torts principles, crushing the leg of a one-legged man may be more costly than injuring a man with two legs: The tortfeasor pays in full for the exceptionally diminished earning capacity of a man without legs as against that of a one-legged man. ${ }^{48}$ Similarly, one of the basic rules of workmen's compensation is that the employer takes the einployee as he finds him. ${ }^{40} \mathrm{Un}$ restricted application of this principle, however, is deemed to discourage liring of the plrysically handicapped and disabled. ${ }^{50}$ Since employment of handicapped persons is an important policy goal, the California Worknien's Compensation Law lias always provided for apportionment of the employer's hability. ${ }^{\text {s1 }}$ Broadly speaking, apportionment seeks to prevent

48 Prosser, TORTS 300-01 (3d ed. 1964).

40 Colonial Ins. Co. v. Industrial Acc. Comm'n [Pedroza], 29 Cal. 2d 79, 172 P.2d 884 (1946) ; Liberty Mut. Ins. Co. v. Industrial Acc. Comm'n [Calabresi], 73 Cal. App. 2d 555, 166 P.2d 908 (1946).

50 See Subsequent Injuries Fund v. Industrial Acc. Comm'n [Patterson], $39 \mathrm{Cal}$. 2d 83, 244 P.2d 889 (1952); Leonard, Rehabilitation, in U.S. DEP'T OF LABOR, BULLETIN 261, WORKMEN's COMmensation Problems 106, 111-12, 114 (1963).

51 The first apportionment statute was Cal. Stat. 1917, c. 586, § $9(\mathrm{~b})(10)$, which provided: "The percentage of permanent disability caused by any injury shall be so computed as to cover the permanent disability caused by that particular injury without reference to any injury previously suffered or any permanent disability caused thereby."

The courts have expressly reserved decision on the point whether hability for temporary disability is also subject to apportionment. Fred Gledhill Chevrolet v. Industrial 
the employer's liability to a handicapped workman from exceeding the amount which would have been due a previously sound man injured under the same circumstances.

The model situation for section 4750 is the case of the one-eyed worker who loses his second eye in an industrial accident. ${ }^{52}$ Loss of one eye under the schedule results, as mentioned before, in a maximum permanent disability rating of thirty percent. Loss of both eyes, or the siglit thereof, results in one hundred percent disability. Since the industrial injury for which the employer's liability attaches has caused the full difference of seventy percent, the employee would be entitled to a seventy percent award against the employer. To prevent this harsh result (which would follow from a strict application of the rule that an employer takes the employee as he finds him), section 4750 provides that the subsequent injury shall be rated independently of the prior loss. As a result, the employer is liable for thirty percent of the total disability. Therefore, he is in no worse position than if he had hired a man with two good eyes.

Apportionment in favor of the employer leaves a portion of the employee's disability uncompensated. To fill this gap in the more severe cases, California maintains a State Subsequent Injuries Fund, which, if certain conditions are met, pays additional benefits to persons whose total permanent disability, regardless of its sources, exceeds seventy percent. ${ }^{53}$ In these instances, the Fund is hable for the uncompensated balance of the employee's disability. Apportionment in favor of the employer thus raises frequently the further issue whether the employee is entitled to an award against the Fund.

\section{B. The Rating of Independent Subsequent Disabilities}

The principle of isolated rating established in section 4750 is easily applied to separate successive disabilities such as the loss of different members. If the disabling events are so far apart that the periods of rehabilitation for the previous and subsequent disabilities do not overlap, there is no reason automatically to reduce the number of benefit weeks provided by the scheduled rating for the subsequent disability;

Acc. Comm'n [Allison], 227 A.C.A. 290, 41 Cal. Rptr. 170 (1964); American Can Co. v. Industrial Acc. Comm'n [Cacioppo], 196 Cal. App. 2d 445, 16 Cal. Rptr. 424 (1961).

52 Subsequent Injuries Fund v. Industrial Acc. Comm'n [Hanson], 217 Cal. App. 2d 322, 31 Cal. Rptr. 508 (1963); Wolski v. Industrial Acc. Comm'n, 70 Cal. App. 2d 427, 161 P.2d 283 (1945). The blindness example is frequently used to illustrate the apportionment principle, e.g., 2 HANNA 265 (1954).

53 CAL. LAB. CoDE $\S 4751$. The Fund is maintained by appropriations from the general funds of the State, Cal. Stat. 1945, c. 1161, § 2. For the history of the Fund, see CaI. Semate Comar. on Labor, Partial Report Relating to Workmen's Compensation 25-26 (1955). 
the Table for Multiple Disability Ratings is lience not necessarily applicable.

Even in these successive cases, isolated rating of the subsequent disability has been attacked on the ground that it may lead to compensation awards which together exceed one hundred percent. In Pacific Gas and Electric Co. v. Industrial Accident Commission [Burton], ${ }^{54}$ ten years after the employee had received an award for a twenty-five and one-half percent disability resulting from a foot injury, he suffered injuries to his cliest, neck and face, and was awarded benefits for seventyseven percent disability. The employer contended that it was illogical to assume the employee could be disabled beyond one hundred percent. This argument was rejected by the court and the award for seventyseven percent uplield. The one hundred percent figure is only a device in reference to which disabilities are measured at any given time; it does not correspond to a real fact. Usually, the disability stemming from an earlier accident is reflected in lower earnings of the employee. The subsequent award, whicl is based upon the average earnings of the period preceding the subsequent injury, ${ }^{55}$ will therefore in any event be smaller than that of a previously healthy man. Consequently, a workman who has lost one arm in an industrial accident and who succeeds in rehabilitating limself so that he can lold a new job would be entitled to a full one hundred percent disability award were he now to lose both his legs. The grant of an independent one liundred percent award can be based on section 4660 (a) directly: Loss of both legs liarms the one-armed man at least as much as it would a sound man, and lie suffers an equal diminution of ability to compete in the labor market.

Different questions arise in cases where several compensable accidents affecting different members occur in such slort intervals as to result in an overlap of payment periods. The discrepancy between actual earning power and disability rating stemming from the complex concept of permanent disability ${ }^{56}$ may result in the collection of multiple benefits by the employee if he is injured while still receiving payments for a previous disability. For several reasons, such multiple benefits are not objectionable. Firstly, payment periods will overlap only temporarily, since disabilities not exceeding seventy percent entitle the employee to

64126 Cal. App. 2d 554, 272 P.2d 818 (1954).

55 CAI. LAB. CODE $\$ 4459$ provides: "The fact that an employee has suffered a previous disability, or received compensation therefor, does not preclude him from compensation for a later injury, or his dependents from compensation for death resulting therefrom, but in determining compensation for the later injury, or death resulting therefrom, his average weekly earnings shall be fixed at the sum which reasonably represents his earning capacity at the time of the later injury."

56 See text accompanying notes 6-9 supra. 
temporary benefits only. ${ }^{57}$ The probability that an employee will be twice industrially disabled beyond seventy percent, so that his lifelong benefits together will exceed the rate for a "total" disability incurred at one time, is too remote to require special consideration. Secondly, the purposes of permanent disability payments are consistent with a collection of multiple benefits for multiple unconnected disabilities: the payments aim to indemmify the workman in some measure for his aggregate loss, only part of which is reflected in a loss of wages. Furthermore, to allow the employer at the time of the second injury a discount in the amount of the previous disability would destroy the incentive for a handicapped person to seek rehabilitation and re-employment, and would constitute a windfall to the employer. Such a discount miglit be justified if handicapped persons were more susceptible to further accidents than others. It has been proved, however, that this is not the case; the handicapped workinan is no special risk. ${ }^{58}$ As the court points out in Burton, the policy of encouraging employment of the handicapped cannot be used to discrimmate against an injured workman and in favor of industry; it does not support a reduction of liability below the amount to which a healthy man would be entitled. ${ }^{59}$ A most striking illustration of independent rating is Subsequent Injuries Fund v. Industrial Accident Commission (Corsinotti), ${ }^{60}$ where it was held that an imbecile with a conclusively presumed disability of one hundred percent was entitled to permanent disability benefits for the employment-connected enucleation of his eye. As Justice Tobriner explained: "The reality of the potential earning power punctures the fiction of the presumed total incapacity."

\section{Overlapping Disabilities: The Problem of Double Compensation}

Under the isolated rating method required by section 4750 , disabilities are given an artificial value. The schedule's judgment of what the subsequent disability would mean to the employee had he been without any prior handicap is the measure, not the actual increase in impairment and decrease in employability. This artificiality is maintained for the sake of apportionment in favor of the employer. It is based upon the assumption that the subsequent injury causes a handicapped person an amount of disability greater than, or at least equal to, the disability which the in-

67 A disability not exceeding $70 \%$ is compensated by payments for up to 280 weeks only. See text accompanying note 8 supra.

${ }^{68}$ See Fabing and Barrow, Encouragement of Employment of the Handicapped, 8 VAND. L. REv. 575, 577-79 (1955).

60 126 Cal. App. 2d at 558, 272 P.2d at 820 (1954).

${ }^{60} 196$ Cal. App. 2d 10, 16 Cal. Rptr. 323 (1961). The case involves the additional benefits payable by the Fund but is based on partial hability of the employer.

61 Id. at 17,16 Cal. Rptr. at 327. 
jury would have caused had the person been healthy. This assumption, however, is not always borne out by the facts. For example, it might be argued that an employee who for many years had suffered from a stiff ankle incurs less additional disability if le subsequently loses the entire leg than would a person who had a good leg. Gardner v. Industrial Accident Commission ${ }^{62}$ in fact so holds, deducting from a fifty-eight and three-fourth percent rating for loss of one leg twelve percent for the previous impairnent of the same leg. The leg was less valuable to the employee and hence should cost the employer less.

Upon the same principle, the supreme court in State Compensation Insurance Fund v. Industrial Accident Commission (Hutchinson) ${ }^{63}$ annulled, as excessive, an award based upon the separate rating of a subsequent back injury. In his first accident the employee received injuries to his neck and shoulder and was compensated by a twenty-six percent judgment rating award for impaired ability to do heavy lifting. The second injury, which affected the low back of the employee, resulted again in permanently impaired ability to do heavy lifting and was given another judgment rating of twenty-six percent. The record shows the rating specialist was ready to testify that the combined disability after the second injury was little more than twenty-six percent, and in any event less than fifty-two percent. ${ }^{64}$ The referee, presumably relying on section 4750 , insisted that the combined disability figure was irrelevant, as only the disability value of the symptoms occurring after the subsequent injury had to be established. ${ }^{05}$ Since the symptoms of the subsequent disabihty were almost identical to those of the first, namely, slight pain increasing to moderate pain on heavy lifting, resulting in impaired ability to do heavy liftimg, the new rating was, like the first one, twentysix percent. The Commission upheld the award on the ground that "if separate parts of the body are injured in separate accidents, each injury must be rated separately and the combined disability is immaterial."100 Thus a hine would be drawn between the Gardner case, where both injuries were to the same anatomical part of the body, and the Burton case, where the injuries affected different parts of the body. In the latter case the method of isolated rating would prevail, while in the former the combined effect might be considered.

This artificial distinction was refuted. Approving of both Gardner and Burton, the supreme court announced a substantive test pursuant

6228 Cal. App. 2d 682, 83 P.2d 295 (1938).

6359 Cal. 2d 45, 377 P.2d 902, 27 Cal. Rptr. 702 (1963).

${ }^{64} I d$. at $47-48$ n. 1, 377 P.2d at 902 n. 1, 27 Cal. Rptr. at 704 n. 1.

65 Ibid.

$66 I d$. at 48,377 P.2d at 905,27 Cal. Rptr. at 705 . 
to which the nature of the disability is decisive. "If successive injuries produce separate and independent disabilities then each is properly rated separately . . . . But if the subsequent injury, even if to a different part of the body, does not alter the earning capacity or ability to compete in the labor market it is not compensable. And if it does alter these factors, it should be compensable only to the extent of the alteration." Since the effects of Hutchinson's successive injuries overlapped, in that le neither lost a further member nor suffered a new limitation of his body functions, the previous disability should have been considered in establishing the rated amount of the subsequent injury. As in Gardner, the pre-existing disability should have been deducted from the combined disability, yielding the extent of the subsequent impairment.

While placing the Gardner rule on a broader basis which makes the deduction method of rating apphicable to all overlapping disability situations, the supreme court did not express itself clearly as to the statutory support for this method. The opinion indicates that section 4663 with its special rule for aggravated diseases does not apply, and that Hutchinson is governed by section $4750 .^{68}$ Yet obviously the deduction method applied by both Gardner and Hutchinson conflicts with the separate rating method contemplated by section 4750 .

It is suggested that only the express abandonment of section 4750 in cases like Hutchinson will prevent further confusion of the different rules purportedly deduced from section 4750 , section 4663 , or both. The evaluation of a subsequent injury is primarily a question of fact for the medical expert and rating specialist. It must be answered in terms of the four factors to be considered under section 4660 (a). If the evidence shows that because of a previous impairment the employee has suffered a lesser degree of disability than the scliedule or a separate rating would mdicate, a question of law is presented, namely, whether the mitigating effect of previous disabilities should inure to the benefit of the employer. The Hutchinson and Gardner cases answer this question in the affirmative. Yet section 4750 does not clearly solve this problem. The section categorically prolibits taking prior impairments into account, and hence would give the employee a full schedule rating. On the other hand, the plurasing of both paragraphs, that the employee "shall not receive . . . in excess ...." and that the employer sliall be hable, "but only for that

07 Id. at 53, 377 P.2d at 908, $27 \mathrm{Cal}$. Rptr. at 708. To be distinguished from the aggravation of a disability, as in Hutchinson, is the case where the employee suffers from recurring symptoms of the same unaltered disability. For example, in Carr v. Industrial Acc. Comm'n, 22 Cal. Comp. Cas. 2 (1957), the Commission refused compensation for a back injury on the ground that petitioner's disablement was not a newly acquired disability, but only a symptom of his pre-existing impairment for which already he had been compensated.

0859 Cal. 2d at 55, 377 P.2d at 909, 27 Cal. Rptr. at 709 (1963). 
portion ... , indicates that the isolated consideration of the subsequent injury under section 4750 was thought by its framers to reduce the employer's liability, not to increase it.

The statute was drafted, as already pointed out, with synergistic disabilities in mind. ${ }^{60}$ In those cases the standard rating serves the purpose of limiting the employer's liability, and thus prevents discrimination in the employment of handicapped workers. Multiple disability cases in which the previous disability reduces the impact of the subsequent disability were apparently overlooked by the drafters of the section. The underlying policy of encouraging the hiring of handicapped workers would not seem to be defeated by an application of section 4750 to the benefit of the employee, so long as the employer's liability is, by definition, limited by the amount payable a previously healthy man. But if the standards of section 4660 are to provide equal treatment for equal disabilities, then it is not justifiable to compensate the employee twice or more for the loss of identical body functions. For example, the standard rating for the amputation of a foot is thirty-five percent, for the amputation of a leg below the knee fifty percent. ${ }^{70}$ Where the total disability is the result of one accident, the einployee would receive benefits computed on the basis of fifty percent; the employee wlo is imjured in two successive accidents would receive a total compensation for eiglity-five percent disability. Loss of an impaired leg is not the same thing as loss of a good leg, and this difference should be taken into account wlien rating the disability of the previously injured workman.

This is not to suggest that the impact of the loss of a stiff leg or a crippled arm is necessarily less than the loss of a good member. Rehabilitation, as by the use of a brace, may be so complete with regard to the previous impairment as practically to reduce its effect to zero. The loss of the crippled member may then require a full schedule or other rating. The point lere made is that the scliedule's ratings are based on the disability to the average liealthy man, and that therefore it cannot be pretended that its ratings are conclusive as to an already disabled man. It follows that literal compliance with section 4750 is not feasible. In every case, an initial determination of the effect of the pre-existing disability upon the newly created disability lias to be made in order to decide wliether the schedule rating is higher or lower than the actual loss. Where it is the same or ligher, as in all cases mvolving different unconnected disabilities, the separate rating approacl is the correct one.

In cases of connected disabilities, the only way of establishing the actual disability value of the subsequent injury is to employ the Hutchin-

69 See text accompanying note 48 supra.

70 Schedule at 13. 
son method: a deduction of the pre-existing disability from the total disability existing after the subsequent mjury. The foot and leg example would be computed roughly ${ }^{71}$ in the following manner: less

Total disability after subsequent injury

previous disability

$-50 \%$

equals

anount of disability caused by the

subsequent injury

This fifteen percent figure is to be compared to the isolated rating for the subsequent disability of fifty percent. Since the disability actually caused is less than the schedule's rating for the healthy man, no issue of apportionment is presented in this situation. To bring the deduction method of rating under section 4750 would strain the language as well as the underlying principle of that provision. It would seem more correct to rely directly upon section 4660 (a).

It may be noted that the separate rating in overlapping disabilities situations is not rejected because the "pyramiding of compensation"72 following from multiple isolated ratings might constitute a windfall to the injured einployee. Considering the necessary monetary limitations on workmen's compensation, ${ }^{73}$ this so-called wimdfall would rarely overcompensate the unfortunate workman for his actual losses. It is concern for a rational basis and fair administration of the present compensation system which compels adherence to the overriding primciple that the employer should be held for disabilities counected with his employment only.

\section{Aggravation of Pre-Existing Disabling Diseases}

A more famihar form of overlapping disabilities is presented by cases in which the pre-existing as well as the subsequent disability are caused by the same disease. Successive heart attacks, for instance, may limit the employee to increasingly light work. It lias already been mentioned

71 I.e., using the standard ratings without regard to occupational and age variation, and also without regard to special factors concerning the employability of the injured workman.

72 Subsequent Injuries Fund v. Industrial Acc. Comm'n [Rogers], 226 A.C.A. 199, 37 Cal. Rptr. 844 (1964).

73 According to the table in CAI. LAB. CODE $\S 4658$, the weekly payments for disabilities beyond $70 \%$ are based upon $15-60 \%$ of average weekly earnings, whereas the short term payments for disabilities below $70 \%$ are uniformly based upon $65 \%$ of average weekly earnings. The maximum average weekly earnings are set by $\S 4460$ at $\$ 80.77$. For a comparison of the maximum effective weekly wage with the average weekly wage, see Riesenfeld, Efficacy and Costs of Workmen's Compensation, 49 CALIF. L. REv. 631, 643-45 (1961). 
that section 4663 precludes compensation for disabilities which stem from the natural progress of a disease. Industrially caused aggravations, on the other hand, are compensable. Since some diseases, particularly old-age diseases, are not wholly caused by the employment, the subsequent disability cannot be computed under the Hutchinson method even though the two disabilities overlap. The difference between the previous disability and the combined disability rated after the subsequent incident would include the natural progression of the disease, a result which violates section 4663 . The proper method of computing the employer's liability in these cases was discussed in Subsequent Injuries Fund $v$. Industrial Accident Commission [Harris], ${ }^{74}$ involving the acceleration of a pre-existing tuberculosis of the spme by a fall during einployment. It was held that the disability attributable to the industrial aggravation could not be determined by merely deducting the pre-existing disability from the combined disability, but that the combined disability should be apportioned in some other way. ${ }^{75}$ Section 4750 , with its prohibition against taking the previous or combined disability into consideration, would make the ratimg of such cases impossible. The method actually used is a variation of the Hutchinson approach, necessitated by the presence of non-employment connected factors.

The relation between the aggravated disease cases and the mere overlapping disabilities cases is perfectly illustrated by State Compensation Insurance Fund v. Industrial Accident Commission [Quick]. ${ }^{70}$ The employee, a deputy sheriff, had had a heart attack in 1955, at which time he was found forty-three and one-half percent disabled. Since fifty percent of his disability was attributed to the normal progress of a preexisting arteriosclerosis, he received an award for twenty-one and threefourths percent permanent disability. In 1959, the employee suffered a second lieart attack which resulted in his total disability. By virtue of the newly amended Labor Code section $3212.5,{ }^{77}$ which set up a special presumption that heart trouble mamifesting itself during service of a deputy slieriff is attributable to the employment, the effect of section 4663 was elinninated. ${ }^{78}$ As a consequence, the subsequent disability was

7444 Cal. 2d 604, 283 P.2d 1039 (1955).

75 The court declares the following method of apportionment: first rate the combined disability, then assign a proportion of it to the later injury and a correlative proportion to the pre-existing (and continuing) disability or impairment. Id. at 608, 283 P.2d at 1041. This method avoids the error committed by the Commission which, by deducting the previous disability from the total disability, had failed to take the natural progress into account. The separation of industrial aggravation and natural progress follows the principles established under $\$ 4663$.

7056 Cal. 2d 681, 365 P.2d 415, 16 Cal. Rptr. 359 (1961).

77 Cal. Stat. 1959, c. 758, § 2.

78 Accordingly, the amount of disability created by the naturally progressing disease 
determined exactly as in Hutchinson and Gardner, by deducting the previously rated forty-three and one-half percent disability from the combined disability of one hundred percent.

IV

\section{THE EVALUATION OF PRE-EXISTING PERMANENT DISABILITIES}

\section{A. The Concept of Previous Disability and Its Use}

"Pre-existing disability" and "combined disability" until now have been used as figures $\mathrm{m}$ the computation of subsequent disabilities. It has been shown that in each subsequent disability case an initial determination must be made whether the previous disability increases or decreases the effect of the subsequent disability, a factual determination that depends on the nature of the two disabilities. Evaluation of the preexisting and combined disabilities is equally important in the computation of the benefits payable by the Subsequent Injuries Fund under Labor Code section $4751 .^{79}$ According to this provision, additional compensation will be awarded for the balance of the combined disability which is not covered by the compensation due from the employer. The role of the Fund as a complementary source of benefits makes it mandatory that the concept of "pre-existing disability" mean the same thing in the computation of both the employer's and the Fund's liability. An illogical exception was created by Subsequent Injuries Fund v. Industrial Accident Commission [Strauss], ${ }^{80}$ whicl granted apportionment to the employer but denied liability of the Fund as to the same unmanifested pre-existing disability, on the ground that section 4751 requires knowledge of the

in the years from 1955 on did not have to be separated from the industrially caused aggravation.

79 Section 4751 provides: "If an employee who is permanently partially disabled receives a subsequent compensable injury resulting in additional permanent partial disability so that the degree of disability caused by the combination of both disabilities is greater than that which would have resulted from the subsequent injury alone, and the combined effect of the last injury and the previous disability or impairment is a permanent disability equal to 70 percent or more of total, le shall be paid in addition to the compensation due under this code for the permanent partial disability caused by the last injury compensation for the remainder of the combined permanent disability existing after the last injury as provided in this article; provided, that either (a) the previous disability or impairment affected a hand, an arm, a foot, a leg, or an eye, and the permanent disability resulting from the subsequent injury affects the opposite and corresponding member, and such latter permanent disability, when considered alone and without regard to, or adjustunent for, the occupation or age of the employee, is equal to 5 percent or more of total, or (b) the permanent disability resulting from the subsequent injury, when considered alone and without regard to or adjustment for the occupation or the age of the employee, is equal to 35 percent or more of total.

80135 Cal. App. 2d 544, 288 P.2d 31 (1955). For a criticism of the Strauss case in this sense, see Note, 44 CaITr. L. REv. 548, 551 n.23 (1956). 
previous disability by the employer. The resulting gap in compensation was closed when Strauss and the appellate cases following it $^{81}$ were overruled by Ferguson v. Industrial Accident Commission ${ }^{82}$ on the point of employer knowledge. The supreme court in Hutchinson expressly declared that a consistent approach should be used for the purposes of apportionment and of Fund liability. ${ }^{83}$

It has furthermore been established since the Ferguson case that "disabihity" has a uniform meaning whether the condition under consideration is pre-existing, subsequent or combined. Ferguson held that a pre-existing impairment must be "labor disabling" in order to support an award under section $4751 .^{84}$ The test, therefore, is whether the previous disability or impairment, had it been caused by an industrial accident, would have been compensable under the standards of section $4660(a) .^{85}$ Its sources-natural disease, congenital defect, prior industrial injury-are irrelevant.

\section{B. The Effect of Rehabilitation}

Under both section 4660 (a) and section 4751 the previous physical disability or impairment must be rated as of the date of the subsequent injury, simce its impact upon the present overall disability of the employee is to be established. Permanent disabilities, by definition, are such as will remain substantially unchanged during the remainder of the injured person's hife. ${ }^{86}$ Nevertheless, change may be brought about by rehabilitation, one of the declared purposes of disability payments. ${ }^{87}$ In Gardner,

81 Appellate cases adopting the Strauss rule that the Fund is not liable unless the employer knew of the pre-existing disability were Urquiza v. Industrial Acc. Comm'n, 144 Cal. App. 2d 322, 300 P.2d 871 (1956); State v. Industrial Acc. Comm'n [Bachracli], 147 Cal. App. 2d 818, 306 P.2d 64 (1957); State v. Industrial Acc. Comm'n [Baldes], 150 Cal. App. 2d 716, 311 P.2d 26 (1957). The Baldes case was re-opened and liability imposed upon the Fund in Subsequent Injuries Fund v. Industrial Acc. Comm'n [Baldes], 53 Cal. 2d 392, 348 P.2d 193, 1 Cal. Rptr. 833 (1960).

8250 Cal. 2d 469, 326 P.2d 145 (1958). Also affected by the Ferguson holding were Hays v. Industrial Acc. Comm'n, 50 Cal. 2d 865, 327 P.2d 904 (1958), and Schlag v. Industrial Acc. Comm'n, 162 Cal. App. 2d 232, 327 P.2d 609 (1958).

8359 Cal. 2d at 55, 377 P.2d at 909, 27 Cal. Rptr. at 709 (1963).

8450 Cal. $2 d$ at 479,326 P.2d at 150 (1958).

85 For applications of the test of labor disabling, sce Subsequent Injuries Fund v. Industrial Acc. Comm'n [Allen], 56 Cal. 2d 842, 17 Cal. Rptr. 144, 366 P.2d 496 (1961) (partial loss of hearing); Subsequent Injuries Fund v. Industrial Acc. Comm'n [Baldes], 53 Cal. 2d 392, 348 P.2d 193, 1 Cal. Rptr. 833 (1960) (schizoplurenia); Tarr v. Industrial Acc. Comm'n, 164 Cal. App. 2d 834, 331 P.2d 417 (1958) (partial loss of hearing).

88 Subsequent Injuries Fund v. Industrial Acc. Comm'n [Rogers], 226 A.C.A. 199, 206, 37 Cal. Rptr. 844, 849 (1964).

87 Gonzales v. Industrial Accident Comm'n, 50 Cal. 2d 360, 368-69, 325 P.2d 993, 999 (dissent). See also text accompanying note 9 suppra. An additional factor has to be considered. At the time of the first award, there is only a slight relationship between the disability rating and the vocational handicap. For a comparison of the two, see CAL. DEp'T 
the original disability figure of twelve percent was carried over to the date of the subsequent injury and was deducted in full. In Hutchinson, the continued validity of the first award was apparently uncontested, presumably because the two accidents were only four months apart. The court in Hutchinson indicated, however, that the computation of benefits might be different if it could be shown that the previous back disability had improved before the occurrence of the second imjury.$^{88}$ Consequently a recent district court of appeals case involving section 4751, Subsequent Injuries Fund v. Industrial Accident Commission [Rogers], ${ }^{89}$ annulled an award on the sole ground that the Commission had failed to allow for rehabilitation with regard to a congenital loss of hearing and the amputation of a leg occurring fifteen years before the industrial accident.

The leading case in the rehabilitation area, Gonzales v. Industrial Accident Commission, ${ }^{90}$ followed the principles first enunciated in Subsequent Injuries Fund v. Industrial Accident Commission [Springer] ${ }^{91}$ The cases involved the evaluation, for purposes of Fund liability, of congenital or early childhood deaf-nnutism in an employee who had suffered an additional disability as the result of an industrial accident. The Commission in each case had based its award upon that rate for loss of speech and hearing which the schedule indicated for the particular age and occupation of the imjured employee. Both courts annulled the awards, instructing the Commission to adjust the disability rating downwards, on the theory that the past lifelong adjustment to the defects rendered the employees far less disabled after their new injuries than they would have been had they lost the faculty of speech and hearing contemporaneously with the industrial accident. This assumption, a question of the evidence in the individual cases, was challenged by a strong dissent in Gonzales, which asserted that a man who becomes a deaf-mute at the age of forty is in a better position than a childhood deaf-mute without the facility of lipreading. ${ }^{92}$ This conflict concerning the inference

of Education, Vocational Remabititation Service, 1 Appendix to Journal of the Senate, Reg. Sess. 39-40, 88-89 (1961). When a disability is evaluated after the employee . has lived with it for some time, the rating can be based upon evidence of past experiences. Although the previous award is not re-opened in the techmical sense, the residual disability at the time of the subsequent injury will be taken into account.

8859 Cal. 2d at 56, 377 P.2d at 909-10, 27 Cal. Rptr. at 709-10 (1963).

89226 A.C.A. 199, 37 Cal. Rptr. 844 (1964).

9050 Cal. 2d 360, 325 P.2d 993 (1958).

.91129 Cal. App. 2d 302, 276 P.2d 820 (1954). See also Belk v. Rothschild, Raffin \& Weirick, 22 Cal. Comp. Cas. 55 (1957); Wallace v. Industrial Acc. Comm'n, 22 Cal. Comp. Cas. 12 (1957).

92 The decision in Gonzales was 4-3. It is interesting to note that the overwhelming evidence before the Commission in the remanded Springer case was that rehabilitation is more difficult for a congemital deaf-mute than for a person who becomes deaf-mute later in 
to be drawn from the expert testimony is of no concern here. The majority and dissent agreed that differences in the extent or duration of rehabilitation may require a deviation from the percentage figures of the schedule.

\section{Previous Disabilities Exceeding One Hundred Percent}

Disregard of the one hundred percent ceiling for a person's disability has already been explained in the context of assessing the employer's hability for a subsequent injury..$^{93}$ The courts have held that a subsequent injury which creates a disability independent of the pre-existing impairment gives rise to compensation benefits regardless of the total sum of disability percentages. ${ }^{94} \mathrm{~A}$ literal reading of section 4751 , which speaks of "an employee who is permanently partially disabled," would support the argument that an employee who was totally disabled before his subsequent injury is not entitled to the Fund benefits provided by that 'section. ${ }^{95}$ The courts have held otherwise. ${ }^{96}$ In Smith v. Industrial Accident Commission, ${ }^{97}$ the Fund was held liable for benefits to an employee : who was totally disabled from arthritis at the time he suffered the subsequent injury. Thus a subsequent disability of five and one-fourth percent there triggered a ninety-four and three-fourths percent award against the Fund. ${ }^{98}$ The danger that severely disabled employees, particularly those suffering from diseases and infirmities natural to old age, might impose enormous financial responsibilities upon the Fund through minimal occupational injuries has since been removed by the creation of high threshold requirements for the subsequent disability."19 No matter how high the pre-existing disability rates, if the subsequent disability is neither above thirty-five percent nor one of the serious injuries enumerated in clause

life. The result was a moderate reduction of the first award of $82 \%$ to $74 \%$. Springer $v$. Ford Motor Co., 21 Cal. Comp. Cas. 335 (1956).

${ }^{93}$ See text accompanying notes 55-61 supra.

94 Subsequent Injuries Fund v. Industrial Acc. Comm'n [Corsinotti], 196 Cal. App. 2d 10, 16 Cal. Rptr. 323 (1961); Pacific Gas \& Elec. Co. v. Industrial Ace. Comm'n [Burton], 126 Cal. App. 2d 554, 272 P.2d 818 (1954).

95 This argument was made by the Subsequent Injuries Fund and upheld by the Commission in Smith v. Industrial Acc. Comm'n, 44 Cal. 2d 364, 282 P.2d 64 (1955). The supreme court annulled the award.

${ }^{06}$ Smith v. Industrial Acc. Comm'n, 44 Cal. 2d 364, 282 P.2d 64 (1955); State v. Industrial Acc. Comm'n [Corsinotti], 196 Cal. App. 2d 10, 16 Cal. Rptr. 323 (1961); Dahlbeck v. Industrial Acc. Comm'n, 135 Cal. App. 2d 394, 287 P.2d 353 (1955).

9744 Cal. 2d 364, 282 P.2d 64 (1955).

98 A similar case is State v. Industrial Acc. Comm'n [Alin], 22 Cal. Comp. Cas, 77 (1957), in which a totally blind employee lost a thumb. The subsequent disability for which the employer was liable amounted to $73 / 4 \%$; $921 / 4 \%$ was assessed against the Subsequent Injuries Fund.

99 CaI. LAB. CODE \& 4751; see note 79 supra. The present version of this section was -enacted in 1959, Cal. Stat. 1959, c. 1034, \&1. 
(a) of section $4751,{ }^{100}$ the employee has not qualified for additional compensation from the Fund.

Double compensation for industrially caused previous disabilities is prevented by section 4753 . The previous impairments enter into the computation of the additional award, but the Fund is credited with all prior payments which the employee has received on account of such previous impairments.

\section{V \\ CONCLUSION}

The law regarding the rating of subsequent disabilities for purposes of workmen's compensation has been developed by the Commission and the courts without much aid from the few statutes dealing with this subject. The basic principles are few. Industry has to take the employee as it finds him, but is not liable for disabilities that would have developed regardless of the industrial accident. ${ }^{101}$ The disability of a previously handicapped person is measured objectively so that liability does not exceed that due a previously healthy person; ${ }^{102}$ provided that in cases of industrial aggravation of a pre-existing disability the employer is liable for the aggravation only. ${ }^{103}$

The complexity of the accepted methods of ratings and apportionment is due largely not to the shortcomings of the present statutory scheme but to the complex purposes for which disability payments are made and to the complex fact situations which have to be evaluated. A more detailed statutory framework could not be expected to simphify these issues or their resolution.

A major source of difficulty, the presently prevailing discrepancy between actual and rated disability, might be eliminated if the rating were based on a careful evaluation of the rehabilitation potential of the individual employee. But apart from the costs which individualized rating would create, it probably would be unwise to abandon the idea of equal treatment wlich underlies the present standard rating system. The common denominator available for all cases is the plysical aspect of disability; the physical loss or impairment must therefore be the overriding factor in disability rating. ${ }^{104}$ Physical loss as such, however, is not

100 For the text of the statute see note 79 supra.

101 CAL. LAB. CODE $\$ 4663$.

102 CAL. LAB. CODE $\$ 4750$.

103 State Compensation Ins. Fund v. Industrial Acc. Comm'n [Hutchinson], 59 Cal. 2d 45, 27 Cal. Rptr. 702, 377 P.2d 902 (1963); Gardner v. Industrial Acc. Comm'n, 28 Cal. App. 2d 682, 83 P.2d 295 (1938).

104 The variations for occupation and age, a unique feature of the California schedule, are secondary factors; they may, however, involve substantial amounts. For the percentage 
measurable, except by arbitrary "price tags."105 The best that can be done is to make ratings equal for equal injuries, ${ }^{106}$ even in differently disposed persons.

If on this basis the standard rating system is accepted, most of the described problems in rating successive disabilities follow. These problems are concerned with the exceptional displacement of the schedule or other standard rate when the prerequisite for this rate, a single industrially caused disability, is not present.

Section 4663 of the Labor Code provides a satisfactory solution for the disability which results from the aggravation of a prior disease, whether arrested or progressing, rather than from an unconnected inpairment. This section will always be difficult to apply because the separation of employment-connected disability from natural disability is a complex medical issue as well as a policy issue. ${ }^{107} \mathrm{~A}$ change of the wording does not seein indicated.

Section 4750 in its present form does not seem adequate to solve cases in which the subsequent disability manifests itself as an increase in a pre-existing disability. Literal compliance with its demand not to take the previous impairment into account would result in multiple compensation for the same disability. In order to prevent an extension of employer hability, the rule of the Hutchinson case should be incorporated into section 4750 . It is recommended that the section be annended to read as follows:

An employee who is suffering from a previous permanent disability and sustains injury thereafter which results in permanent disability shall not receive from the employer compensation for the later disability in excess of

(a) the compensation allowed for such disability when considered by itself and not in conjunction with or in relation to the previous disability, or

(b) the compensation allowed for the increase in disability which is the difference between the previous disability and the combined disability,

whichever is smaller.

The employer shall not be liable for compensation to such an em-

range of these variations, see THIRD REPORT 12-13. Comments from other states on the occupation and age variation may be found in $i d$. at $19-28$.

1052 LARSON, The LAW OF WORKMEN'S COMPENSATION $\$ 58.10$ (1961).

106 An investigation by the California Senate Interim Committee on Workmen's Compensation Benefits showed that the rating process in its present form does not guarantee consistent ratings for equal injuries. THIRD REPORT 14-16. For present purposes it is assumed that scheduled ratings yield equal results for equal injuries, or at least that these results are more consistent than those obtamable from completely free rating.

107 Maltony v. Fisher Body Div. of Gen. Motors Corp., 22 Cal. Comp. Cas. 52 (1957): 
ployee for the combined disability, but only for that portion allowed by this section for the later disability. ${ }^{108}$

The proposed subsection (b) would be equally applicable in cases in which the aggravation of a previous disability or physical impairment is caused both by an industrial accident and by a naturally progressing disease. This situation, illustrated by the Harris case, ${ }^{109}$ calls for an apphication of section 4663 together with section 4750 . Section 4663 is used to ehminate the contemporaneous disabling results of the nonindustrial disease, and section 4750 provides for an apportionment of the subsequent as against the pre-existing disability. Since a subsequent disability in conjunction with a disease usually overlaps with the previous disability stemming from the same disease, section 4750 is again inapphicable, as in the Hutchinson case, unless the statute is amended so as to permit a comparison of the previous disability with the combined disability.

\section{Wiebke Buxbaum}

108 Apart from the addition of subsection (b) the language has been altered in some respects in order to establish the uniform use of the term "permanent disability."

109 Subsequent Injuries Fund v. Industrial Acc. Comm'n [Harris], 44 Cal. 2d 604, 283 P.2d 1039 (1955). 